\title{
Normalizing Treatment Influence on the Forged Steel SAE 8620 Fracture Properties
}

\author{
Paulo de Tarso Vida Gomes ${ }^{\text {a**, Julio Ricardo Barreto Cruz }}{ }^{\mathrm{a}}$,Emerson Giovani Rabelo ${ }^{\mathrm{a}}$, Miguel Mattar Neto ${ }^{\mathrm{b}}$ \\ ${ }^{a}$ Centro de Desenvolvimento da Tecnologia Nuclear M. Mattar Neto \\ Rua Mário Werneck s/n, 30123-970 Cidade Universitária, Belo Horizonte - MG \\ ${ }^{\mathrm{b}}$ Instituto de Pesquisa Energéticas e Nucleares \\ Travessa R, 400, 05508-900 Cidade Universitária, São Paulo - SP
}

Received: September 24, 2004; Revised: January 5, 2005

\begin{abstract}
In a PWR nuclear power plant, the reactor pressure vessel (RPV) contains the fuel assemblies and reactor vessels internals and keeps the coolant at high temperature and high pressure during normal operation. The RPV integrity must be assured all along its useful life to protect the general public against a significant radiation liberation damage. One of the critical issues relative to the VPR structural integrity refers to the pressurized thermal shock (PTS) accident evaluation. To better understand the effects of this kind of event, a PTS experiment has been planned using an RPV prototype. The RPV material fracture behavior characterization in the ductile-brittle transition region represents one of the most important aspects of the structural assessment process of RPV's under PTS. This work presents the results of fracture toughness tests carried out to characterize the RPV prototype material behavior. The test data includes Charpy energy curves, $\mathrm{T}_{0}$ reference temperatures for definition of master curves, and fracture surfaces observed in electronic microscope. The results are given for the vessel steel in the "as received" and normalized conditions. This way, the influence of the normalizing treatment on the fracture properties of the steel could be evaluated.
\end{abstract}

Keywords: fracture mechanics, master curve, reference temperature, pressurized thermal shock

\section{Introduction}

In a Pressurized Water Reactor (PWR), the reactor pressure vessel (RPV) contains the fuel assemblies and its internals, keeping the coolant at high temperature $\left(\sim 275^{\circ} \mathrm{C}\right)$ and high pressure $(\sim 16 \mathrm{bar})$ under normal operation conditions. The RPV is designed, built and tested according to stringent codes and standards so that its structural integrity can be assured during its lifetime ${ }^{1,2}$.

The so-called Pressurized Thermal Shock (PTS) accident has been considered an important safety issue since the transient occurred at Rancho Seco Nuclear Power Plant (NPP) in $1978^{3}$. The PTS is a transient where a sudden cooling causes a thermal shock in the RPV wall while the pressure is kept constant or is increased as the system is re-pressurized. The thermal stresses due to the sudden cooling combined with the mechanical stresses due to the pressure result in high tensile stresses in the RPV wall, which have a maximum value in its inner surface.

At temperatures below the RPV material NDT (Nil Ductility Temperature), the fracture toughness decreases. Thus, the high stresses that occur during the PTS may cause the propagation of small cracks present in the RPV wall. This issue is aggravated by the decreasing in the material fracture toughness from the fast neutron fluence in the RPV wall next to the reactor core region ${ }^{4}$.

Many approaches, based on structural analyses and fracture assessments, have been applied to find the safety margins against the RPV burst during PTS postulated accidents. In all approaches, the mechanical and fracture material properties as well as the defect characteristics (real or postulated) are needed.

\section{Materials and Methods}

An experiment was designed to assess the behavior of a RPV prototype under PTS. The pressure vessel was built using the forged

e-mail: gomespt@cdtn.br

1) Wallin K. [Personal Communication by e-mail] 2003 Sept 20 . steel SAE 8620, with an inner diameter of $500 \mathrm{~mm}$, a height of $1000 \mathrm{~mm}$ and a wall thickness of $85 \mathrm{~mm}$. The prototype dimensions were defined from thermodynamics calculations using the code ACIBRPV for a cooling condition as close as an actual RPV cooling ${ }^{5}$. The material choice was based on the chemical composition similarity with the Angra 1 nuclear power plant material ${ }^{5}$. The steel properties characterization, in "as received" and normalized conditions, was obtained from tensile, Charpy impact and J-integral tests. The crack arrest reference temperature $\mathrm{T}_{0}$ was defined using an indirect method (1) and the results from the instrumented Charpy tests ${ }^{6}$. All specimens for the material in the "as received" condition were extracted in RC, CR and RL directions according to ASTM-E237. The specimens for the material normalized condition were extracted only in RC direction.

\subsection{Tensile tests}

The material tensile tests in the "as received" and normalized conditions were performed using three specimens with a diameter of $4 \mathrm{~mm}$, in each direction according to ASTM-E $8^{8}$. The final values were taken as the average of the values obtained in each orientation. The test temperature was the same used in the J-integral tests for master curve definition. ASTM-E 1921/979 recommends the use of Equation 1 to obtain the test temperature.

$$
\mathrm{T}=\mathrm{T}_{28 \mathrm{~J}}-50^{\circ} \mathrm{C}
$$

\subsection{Charpy impact tests}

The Charpy impact tests to obtain the ductile-to-brittle transition curve were performed in a temperature range from $-46{ }^{\circ} \mathrm{C}$ to $200{ }^{\circ} \mathrm{C}$, using an Ametek impact equipment, with a 320 Joule ham- 
mer. The instrumented Charpy impact tests were performed in an Instron impact equipment, model PW30. For the determination of the temperature where the absorbed energy was 28 Joule the following equation was used:

$$
\mathrm{Y}=\mathrm{P}_{1}+\mathrm{P}_{2} \tanh \left(\left(\mathrm{X}-\mathrm{P}_{3}\right) / \mathrm{P}_{4}\right)
$$

$\mathrm{Y}$ is the absorbed energy, $\mathrm{X}$ is the test temperature and $\mathrm{P}_{1}, \mathrm{P}_{2}$, $\mathrm{P}_{3}$ e $\mathrm{P}_{4}$ are the curve fitting parameters from the evaluation using the program Origin 6.1. Some fracture surfaces were seen in a Jeol electronic microscope, model JSM 5310, with a magnification of 500 times.

\subsection{Master curve}

The determination of the reference temperatures $\mathrm{T}_{0}$ and the definition of the master curves followed the ASTM-E 1921/979 procedures. Pre-cracked Charpy specimens were used as SE(B) specimens. The J-integral values were obtained, using a servo-hydraulic Instron equipment with $100 \mathrm{kN}$ capacity and the program Fast Track Console, at $-7^{\circ} \mathrm{C}$ for the material in the "as received" condition and at $-88^{\circ} \mathrm{C}$ for the material in normalized condition. These test temperatures were obtained using Equation 1, where $\mathrm{T}$ is the Charpy test temperature and $\mathrm{T}_{28 \mathrm{I}}$ is the temperature obtained from Equation 2, corresponding to the 28 Joule absorbed energy in the Charpy tests.

\section{Results and Discussion}

The obtained results from tensile tests for the material in the "as received" condition and in the normalized condition are shown in Tables 1 and 2, respectively. For the material in the "as received" condition, it can be noticed the small variation in the results for the orientations RC, CR and RL, at the same temperature. This can be explained by the fact that due the forging process the material became insensitive to the evaluated orientation. Due to this reason, the steel in the normalized condition was tested only in one orientation.

Figure 1 shows the ductile-to-brittle transition curves in the orientation CR for the steel SAE 8620 . The temperature corresponding to an absorbed energy of 28 Joule was $43{ }^{\circ} \mathrm{C}$ for the "as received" condition (Figure 1a) and $-38{ }^{\circ} \mathrm{C}$ for the normalized condition (Figure 1b). These values came from Equation 2.
In Figure 2a-c, the fracture surfaces of the SAE 8620 steel specimens in the "as received" condition, tested at temperatures of $-46^{\circ} \mathrm{C}$, $24{ }^{\circ} \mathrm{C}$ and $58{ }^{\circ} \mathrm{C}$, respectively, are shown. In Figure 3a-c, the same fracture surfaces are shown with a magnification of 500 times. "Pure" cleavage fractures can be observed at $-46^{\circ} \mathrm{C}$ and $24^{\circ} \mathrm{C}$, and a cleavage region with a small quantity of dimples at $58{ }^{\circ} \mathrm{C}$. This represents a completely brittle behavior at $-46^{\circ} \mathrm{C}$ and $24^{\circ} \mathrm{C}$, and the beginning of a ductile fracture at $58^{\circ} \mathrm{C}$, in agreement with the values of transition temperatures, around $43{ }^{\circ} \mathrm{C}$, obtained from Equation 2 .

In Figure 4a-c, the fracture surfaces of the SAE 8620 steel specimens in the normalized condition, tested at temperatures of $-54{ }^{\circ} \mathrm{C}$, $-23{ }^{\circ} \mathrm{C}$ and $0{ }^{\circ} \mathrm{C}$, respectively, are shown. In Figure 5a-c, the same fracture surfaces are shown with a magnification of 500 times. It can be observed cleavage fracture characteristics at $-54{ }^{\circ} \mathrm{C}$. In the other pictures, for higher temperatures, one can see surfaces with mixed characteristics (locations with the presence of dimples, which are typical of ductile fracture and other regions with clear cleavage characteristics).

For CR specimens at $-7^{\circ} \mathrm{C}$, in the "as received" condition, the $\mathrm{J}_{\mathrm{C}}$ values from the tests and the calculated $\mathrm{K}_{\mathrm{JC}}$ and $\mathrm{T}_{0}$, according to the used standard, are shown in Table 3.

In Figures $6 \mathrm{a}$ and $6 \mathrm{~b}$, the master curve (with the tolerance limits) and the Weibull distribution for crack initiation in SAE 8620 steel CR specimens, in the "as received" condition, tested at $-7^{\circ} \mathrm{C}$, are shown. Some tested specimens were discarded because they do not show valid $\mathrm{J}_{\mathrm{C}}$ values according to the used standard. All specimens showed popin and were evaluated and approved as $\mathrm{J}_{\mathrm{C}}$ at instability, according to the used standard ${ }^{11}$. This behavior was expected due to the material toughness observed in the results from Charpy impact tests.

For CR specimens at $-88{ }^{\circ} \mathrm{C}$, in the normalized condition, the $\mathrm{J}_{\mathrm{C}}$ values from the tests and the calculated $\mathrm{K}_{\mathrm{JC}} \mathrm{e} \mathrm{T}_{0}$, according to the used standard, are shown in Table 4.

In Figures $7 \mathrm{a}$ and $7 \mathrm{~b}$, the master curve (with the tolerance limits) and the Weibull distribution for crack initiation in SAE 8620 steel CR specimens, in the normalized condition, tested at $-88^{\circ} \mathrm{C}$, are shown.

In Figures $8 \mathrm{a}$ and $8 \mathrm{~b}$, the master curve for crack arrest in $\mathrm{CR}$ specimens, in the "as received" and normalized conditions, obtained from instrumented Charpy impact tests, are shown.

In Figures 9a and 9b, the master curves for crack arrest and crack

Table 1. Values from tensile tests of the SAE 8620 steel in the "as received" condition.

\begin{tabular}{|c|c|c|c|c|c|c|c|}
\hline \multirow[b]{2}{*}{$\begin{array}{l}\text { Specimen } \\
\text { Direction }\end{array}$} & \multirow[b]{2}{*}{$\begin{array}{c}\text { Test Temperature } \\
\left({ }^{\circ} \mathrm{C}\right)\end{array}$} & \multicolumn{2}{|c|}{ Yielding Point } & \multicolumn{2}{|c|}{ Ultimate Tensile Stress } & \multicolumn{2}{|c|}{ Fracture Stress } \\
\hline & & $\begin{array}{l}\text { Value } \\
\mathrm{MPa}\end{array}$ & $\begin{array}{c}\text { Standard } \\
\text { Deviation } \\
\mathrm{MPa} \\
\end{array}$ & $\begin{array}{l}\text { Value } \\
\mathrm{MPa}\end{array}$ & $\begin{array}{c}\text { Standard } \\
\text { Deviation } \\
\mathrm{MPa}\end{array}$ & $\begin{array}{l}\text { Value } \\
\mathrm{MPa}\end{array}$ & $\begin{array}{c}\text { Standard } \\
\text { Deviation } \\
\mathrm{MPa} \\
\end{array}$ \\
\hline $\mathrm{CR}$ & 24 & 279.0 & 0.31 & 491.0 & 0.47 & 338.0 & 0.61 \\
\hline $\mathrm{CR}$ & -7 & 295.0 & 0.42 & 533.0 & 0.73 & 380.0 & 0.48 \\
\hline $\mathrm{RC}$ & -7 & 302.0 & 0.48 & 523.0 & 0.87 & 371.0 & 0.64 \\
\hline
\end{tabular}

Table 2. Values from tensile tests of the SAE 8620 steel in the normalized condition.

\begin{tabular}{|c|c|c|c|c|c|c|c|}
\hline \multirow[b]{2}{*}{$\begin{array}{l}\text { Specimen } \\
\text { Direction }\end{array}$} & \multirow[b]{2}{*}{$\begin{array}{c}\text { Test Temperature } \\
\left({ }^{\circ} \mathrm{C}\right)\end{array}$} & \multicolumn{2}{|c|}{ Yielding Point } & \multicolumn{2}{|c|}{ Ultimate Tensile Stress } & \multicolumn{2}{|c|}{ Fracture Stress } \\
\hline & & $\begin{array}{l}\text { Value } \\
\mathrm{MPa}\end{array}$ & $\begin{array}{c}\text { Standard } \\
\text { Deviation } \\
\mathrm{MPa} \\
\end{array}$ & $\begin{array}{l}\text { Value } \\
\mathrm{MPa}\end{array}$ & $\begin{array}{c}\text { Standard } \\
\text { Deviation } \\
\mathrm{MPa}\end{array}$ & $\begin{array}{l}\text { Value } \\
\mathrm{MPa}\end{array}$ & $\begin{array}{c}\text { Standard } \\
\text { Deviation } \\
\mathrm{MPa} \\
\end{array}$ \\
\hline $\mathrm{CR}$ & 24 & 227 & 0.01 & 413 & 0.31 & 302 & 0.80 \\
\hline $\mathrm{CR}$ & -88 & 325 & 0.77 & 552 & 0.72 & 391 & 0.39 \\
\hline
\end{tabular}


initiation for SAE 8620 steel CR specimens are shown together, in the "as received" and normalized conditions. It can be noticed that in the "as received" condition the curves are almost coincident due to the small difference between the reference temperatures $\mathrm{T}_{\mathrm{KIA}}$ e $\mathrm{T}_{\mathrm{KIC}}$, which is only $2.1^{\circ} \mathrm{C}$.

According to Wallin et $\mathrm{al}^{6}{ }^{6}$, the proximity of the curves for $\mathrm{K}_{\mathrm{IC}}$ and $\mathrm{K}_{\mathrm{IA}}$ increases the probability of the crack arrest. If the growing of a pre-existent crack in the RPV wall is triggered it stops almost instantaneously when the crack reaches regions with slightly higher temperatures. This behavior is not expected in ferritic steels like SAE 8620. This apparent incoherence is possibly due to the indirect and empirical method used to estimate the $\mathrm{K}_{\mathrm{IA}}$ curve, which is still

Charpy Impact Energy- "as received" SAE 8620 steel RC orientation

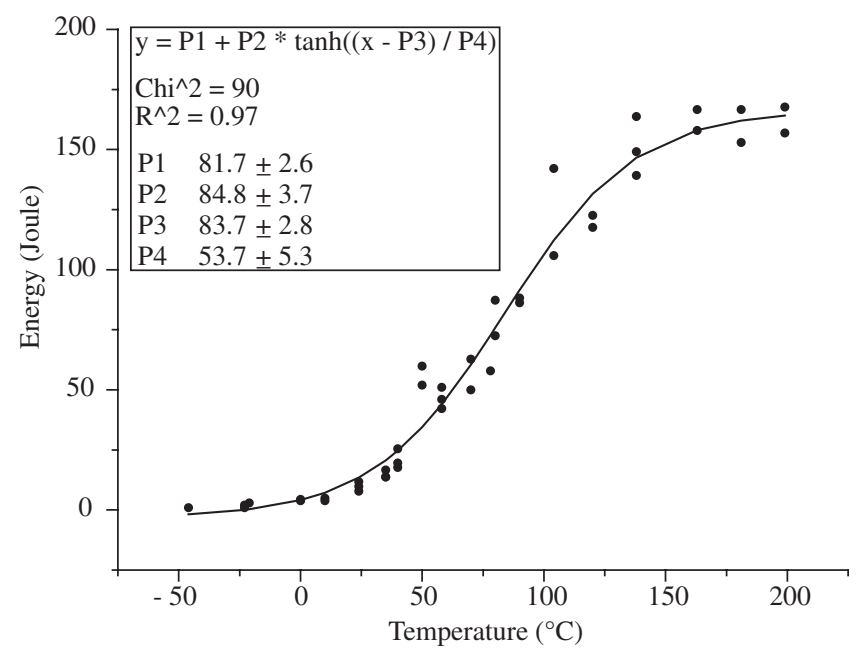

(a)

Charpy Impact Energy - Normalized SAE 8620 steel

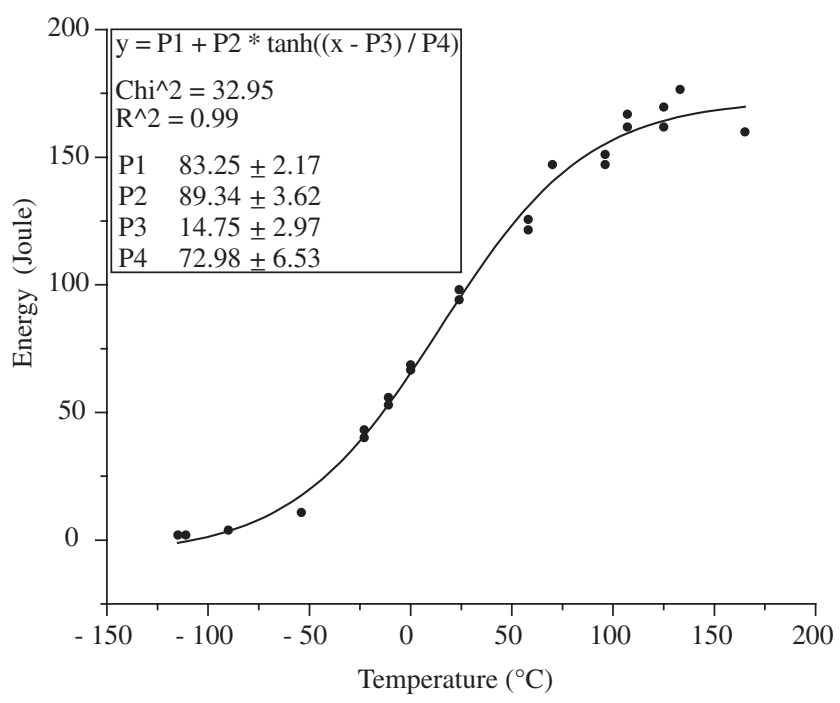

(b)

Figure 1. Ductile-to-brittle transition curves in the direction CR for the SAE 8620 steel in the: a) "as received"; b) normalized conditions. in development and, therefore, it is not standardized yet. It is worth noting that this indirect method was used because there was no material on hand for crack arrest tests. However, after the completion of the PTS experiment, vessel parts will be cut for defect inspection, so that material will be made available. Thus, crack arrest tests will be performed and the results will be compared with the estimations now presented.

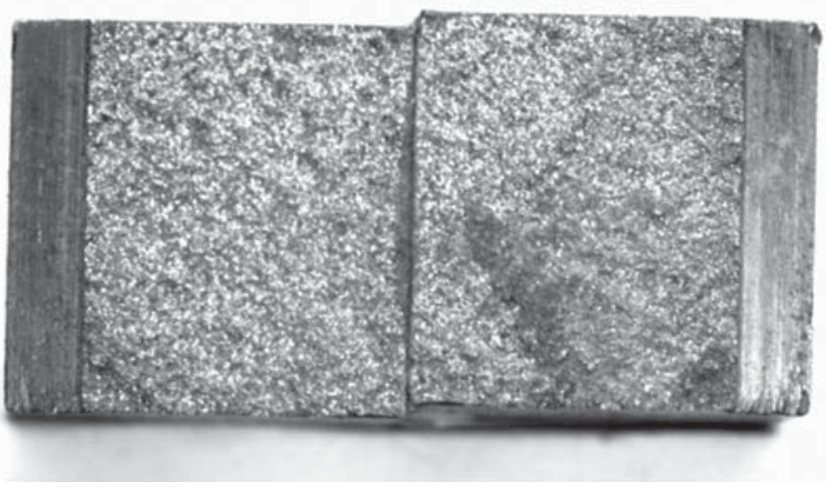

(a)

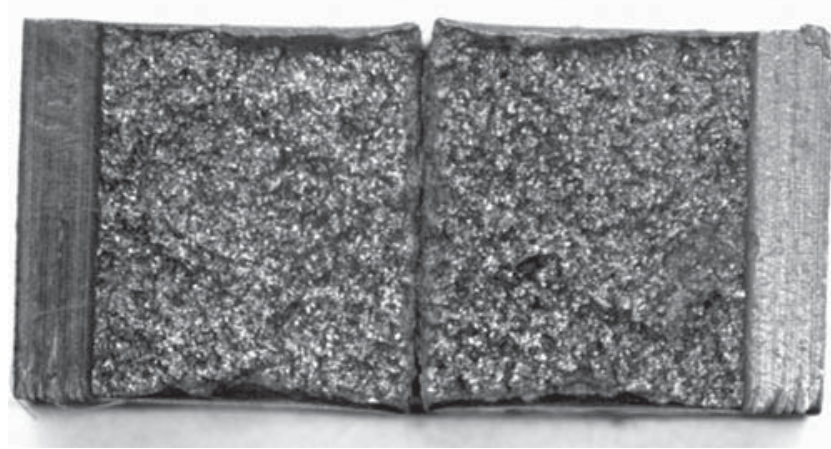

(b)

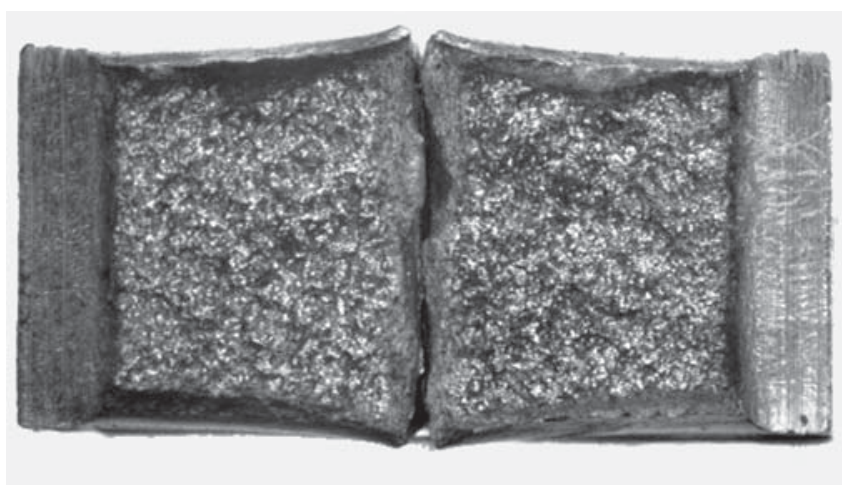

(c)

Figure 2. Charpy specimens fracture surfaces, steel in "as received" condition, observed in electronic microscope (no magnification): a) Tested at $-46{ }^{\circ} \mathrm{C}$; b) Tested at $24^{\circ} \mathrm{C}$; c) Tested at $58^{\circ} \mathrm{C}$. 


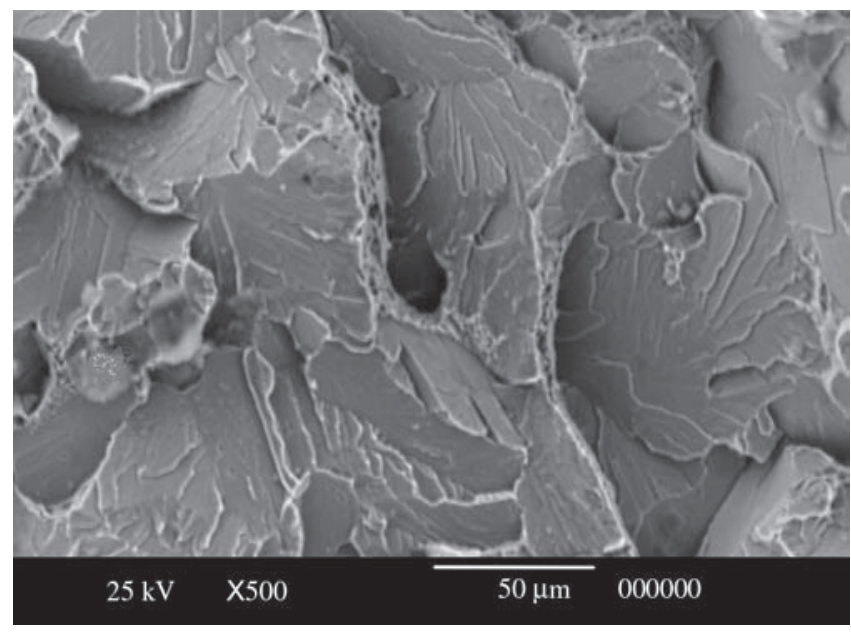

(a)

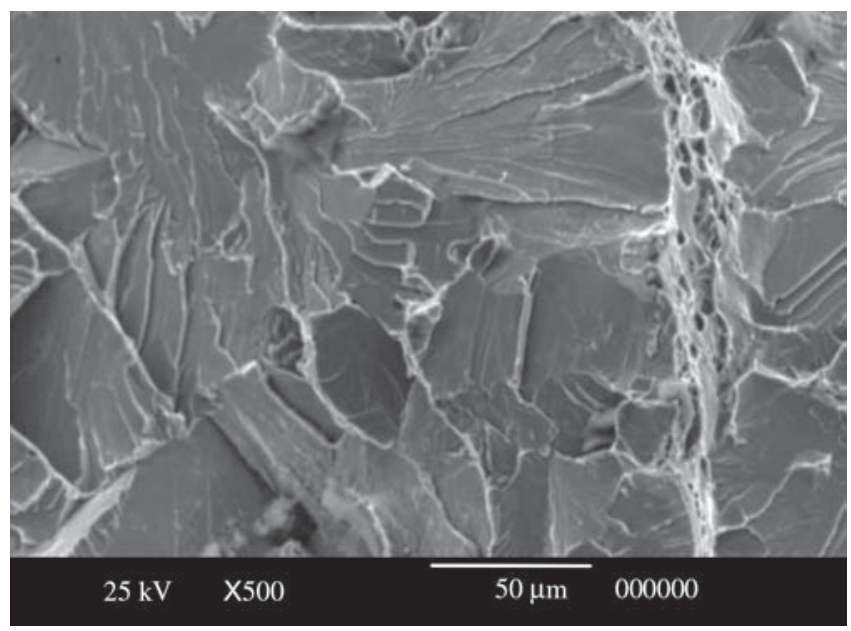

(b)

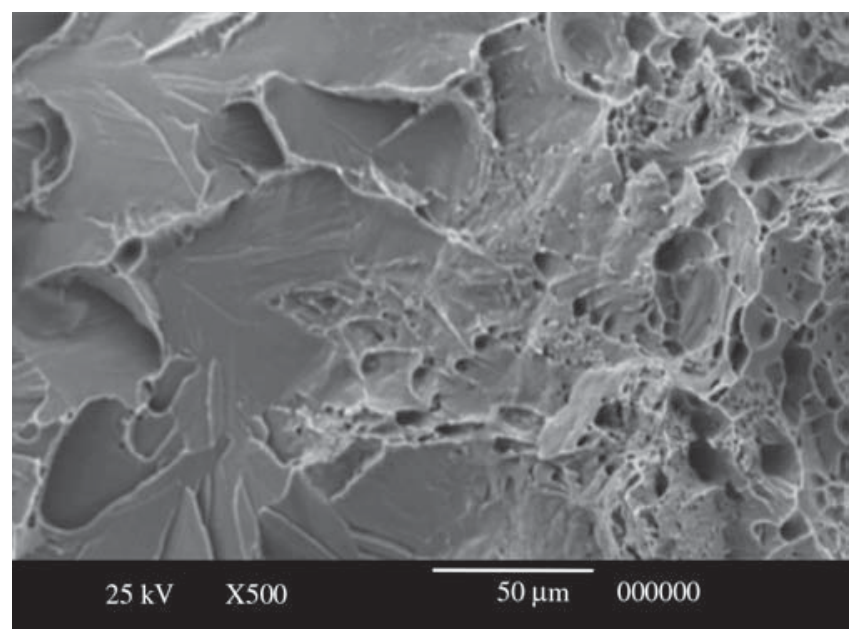

(c)

Figure 3. Charpy specimens fracture surfaces, steel in "as received" condition, observed in electronic microscope (magnification of 500 times): a) Tested at - $46{ }^{\circ} \mathrm{C}$; b) Tested at $24^{\circ} \mathrm{C}$; c) Tested at $58{ }^{\circ} \mathrm{C}$.

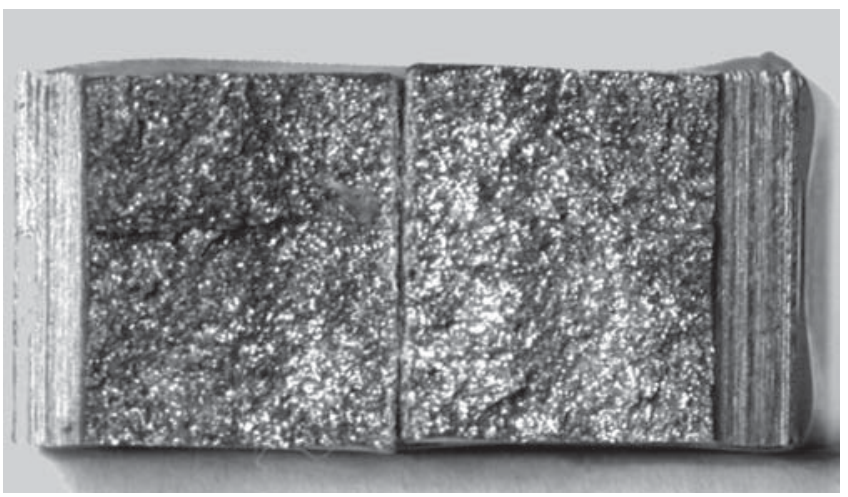

(a)

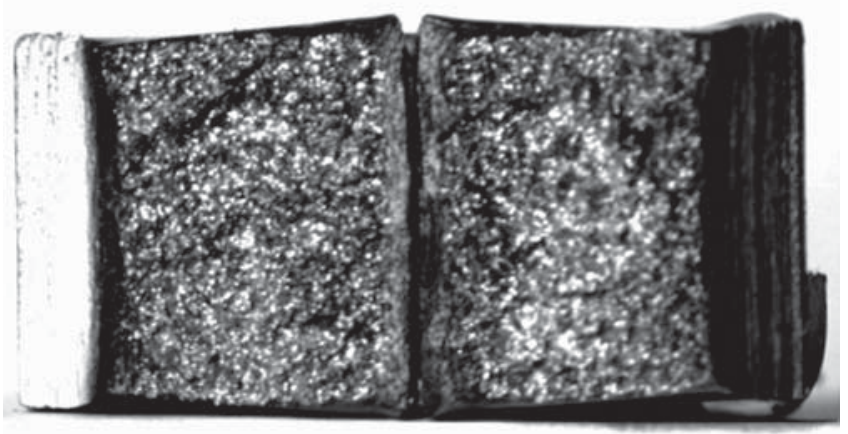

(b)

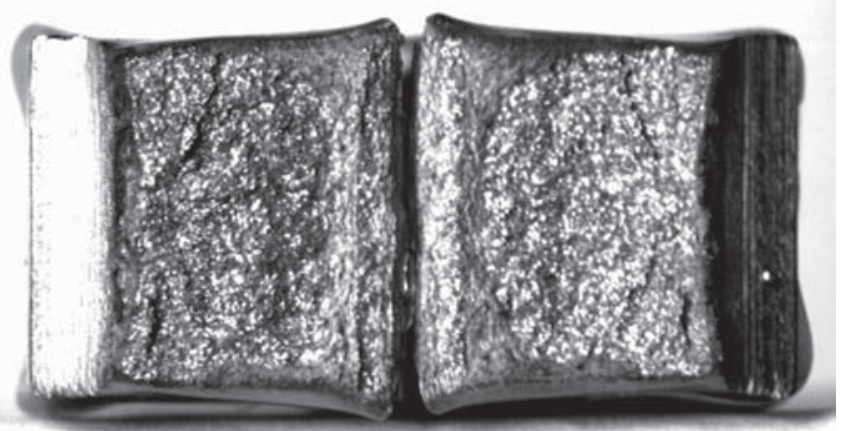

(c)

Figure 4. Charpy specimens fracture surfaces, steel in normalized condition, observed in electronic microscope (no magnification): a) Tested at $-54^{\circ} \mathrm{C}$; b) Tested at $-23{ }^{\circ} \mathrm{C}$; c) Tested at $0{ }^{\circ} \mathrm{C}$. 


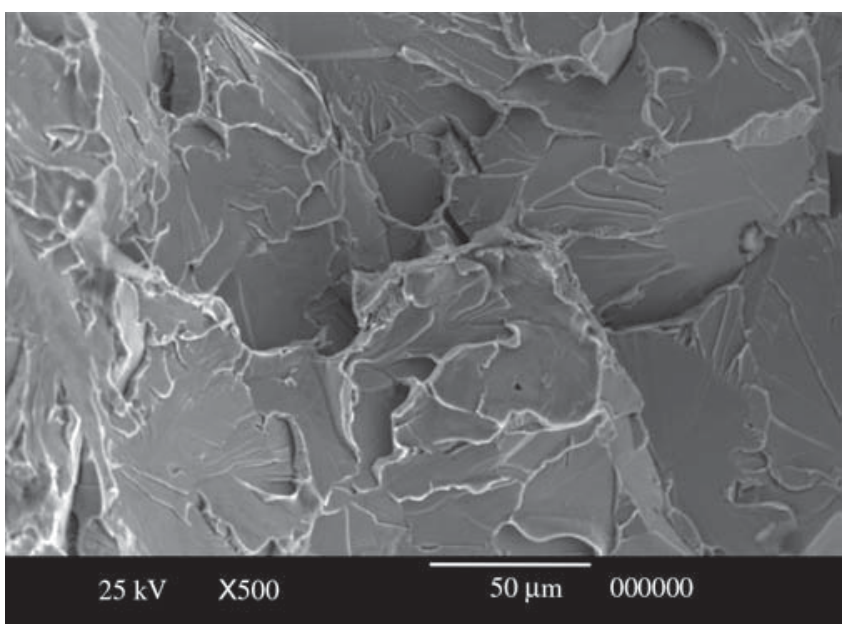

(a)

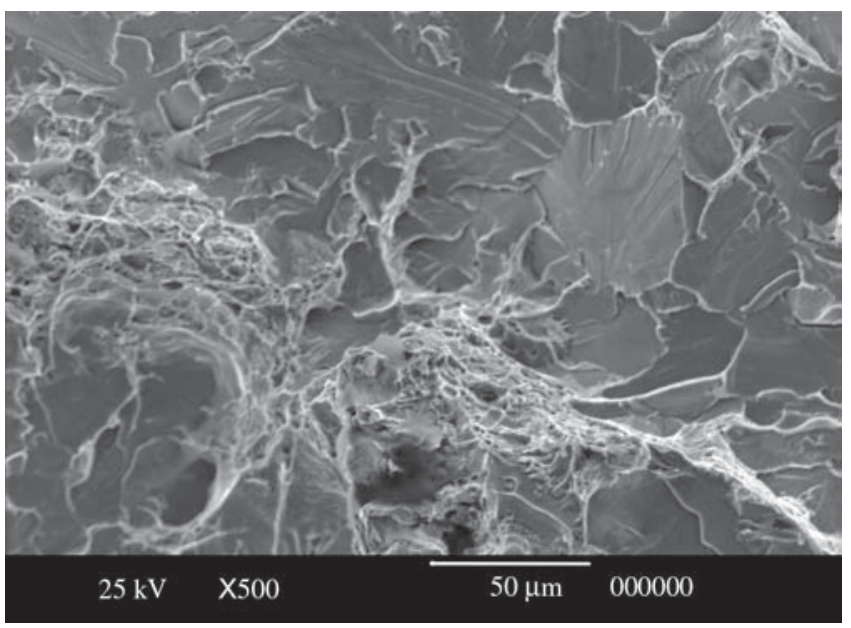

(b)

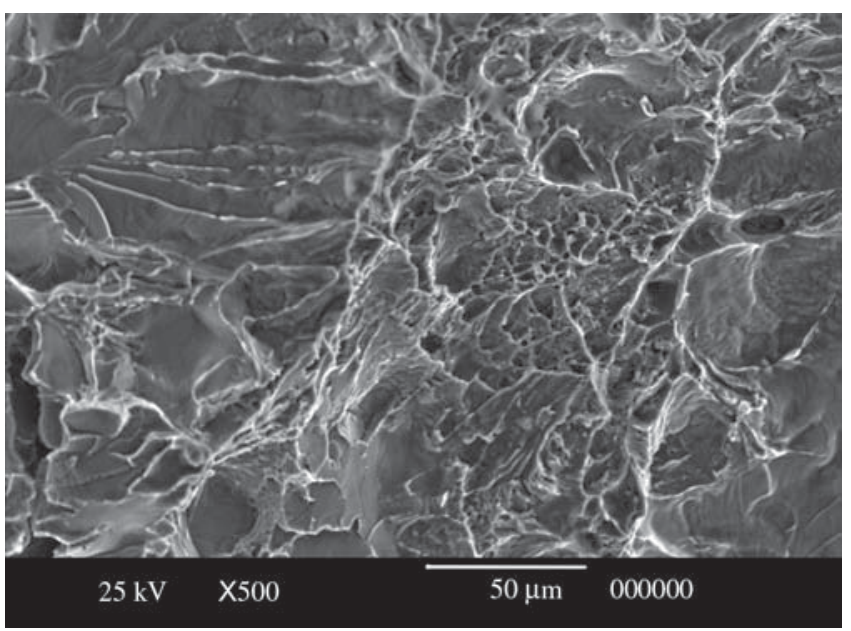

(c)

Figure 5. Charpy specimens fracture surfaces, steel in normalized condition, observed in electronic microscope (magnification of 500 times): a) Tested at $-54{ }^{\circ} \mathrm{C}$; b) Tested at $-23{ }^{\circ} \mathrm{C}$, c) Tested at $0{ }^{\circ} \mathrm{C}$.

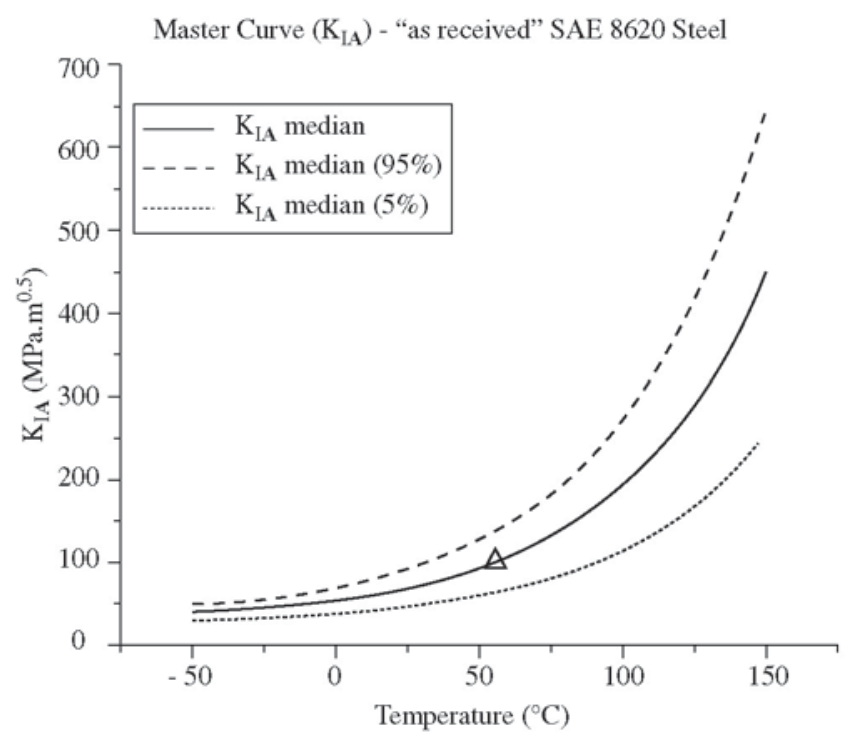

(a)

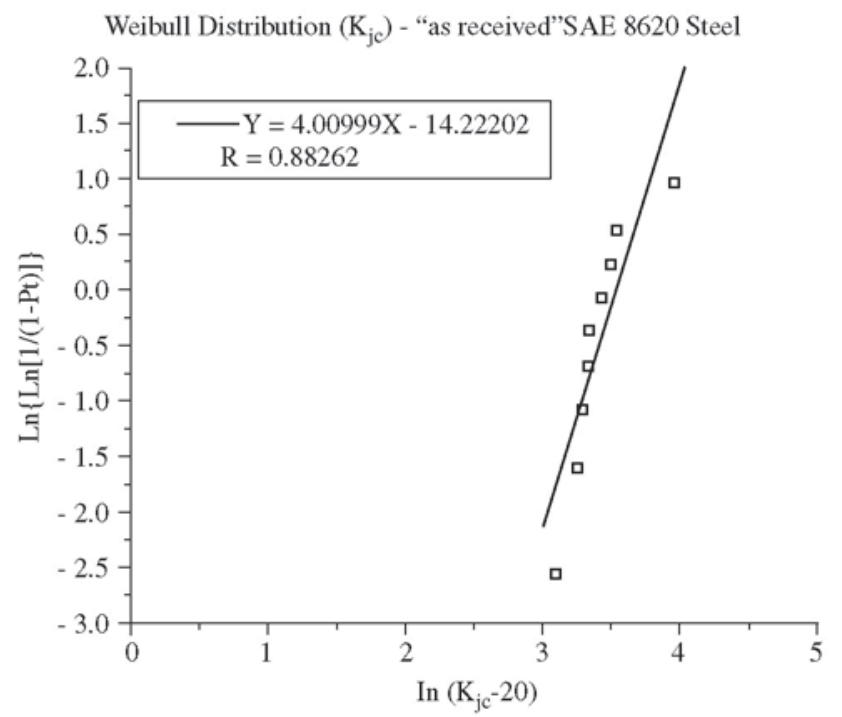

(b)

Figure 6. Master Curve and its tolerance limits: a) and Weibull distribution for crack initiation; b) SAE 8620 steel CR specimens, "as-received" condition, at $-7{ }^{\circ} \mathrm{C}$.

\section{Conclusions}

From the obtained results, regarding the fracture properties of the SAE 8620 steel in the "as received" and normalized conditions, the following conclusions can be addressed:

The SAE 8620 steel shows a high embrittlement level in the "as received" condition. However, this is very convenient in a PTS experimental assessment where it is important to simulate the RPV material properties embrittled by a high flux of fast neutrons.

The normalization treatment, performed according to the manufacturer's specifications, caused a high increase in the material toughness.

The Reference Temperatures $\mathrm{T}_{0}$ (called here $\mathrm{T}_{\mathrm{KIA}}$ for crack arrest and $\mathrm{T}_{\mathrm{KIC}}$ for crack initiation) are very close to each other for the studied material in the "as received" condition. 
Table 3. Experimental values of $\mathrm{J}_{\mathrm{C}}$, and calculated $\mathrm{K}_{\mathrm{JC}}$ and $\mathrm{T}_{0}$ at $-7^{\circ} \mathrm{C}$.

\begin{tabular}{|c|c|c|c|c|c|}
\hline $\begin{array}{c}\mathrm{J}_{\mathrm{C}} \\
\left(\mathrm{kJ} \cdot \mathrm{m}^{2}\right)\end{array}$ & $\begin{array}{l}\mathrm{K}_{\mathrm{JC}}(0,39 \mathrm{~T}) \\
\left(\mathrm{MPa} \cdot \mathrm{m}^{1 / 2}\right)\end{array}$ & $\begin{array}{c}\mathrm{K}_{\mathrm{JC}}(1 \mathrm{~T}) \\
\left(\mathrm{MPa} \cdot \mathrm{m}^{1 / 2}\right)\end{array}$ & $\begin{array}{l}\mathrm{K}_{\mathrm{JC}}(\mathrm{med}) \\
\left(\mathrm{MPa} \cdot \mathrm{m}^{1 / 2}\right)\end{array}$ & $\begin{array}{l}\text { Test Temperature } \\
\left({ }^{\circ} \mathrm{C}\right)\end{array}$ & $\begin{array}{c}\mathrm{T}_{0} \\
\left({ }^{\circ} \mathrm{C}\right)\end{array}$ \\
\hline 19.21 & 63.5 & 54.5 & & & \\
\hline 35.45 & 86.3 & 72.5 & & & \\
\hline 14.79 & 55.7 & 48.3 & & & \\
\hline 16.61 & 59.1 & 50.9 & & & \\
\hline 13.22 & 52.7 & 45.9 & 52.27 & -7 & 53.3 \\
\hline 14.63 & 55.4 & 48.1 & & & \\
\hline 18.22 & 61.9 & 53.2 & & & \\
\hline 13.73 & 53.7 & 46.7 & & & \\
\hline 11.04 & 48.1 & 42.3 & & & \\
\hline
\end{tabular}

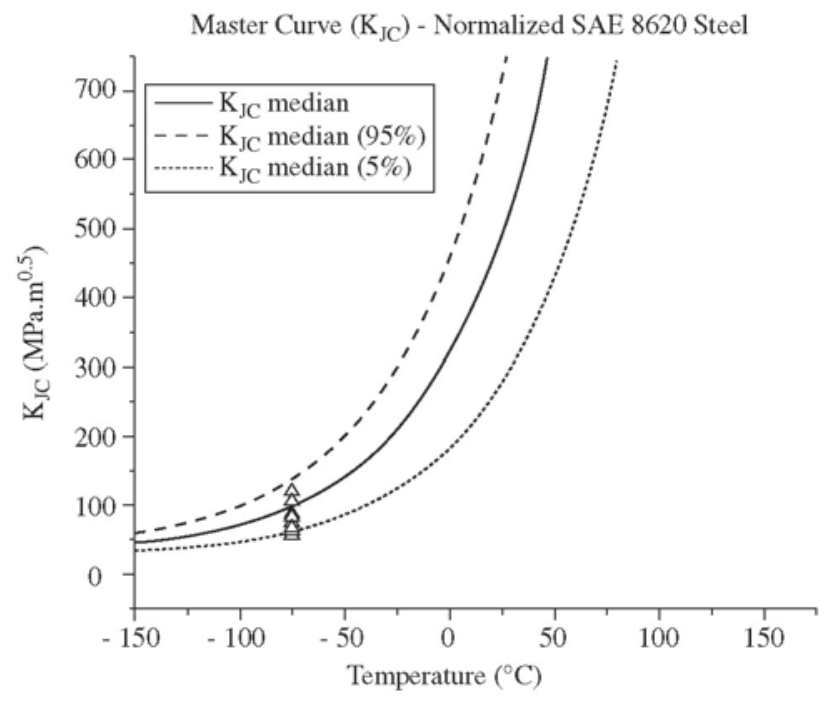

(a)

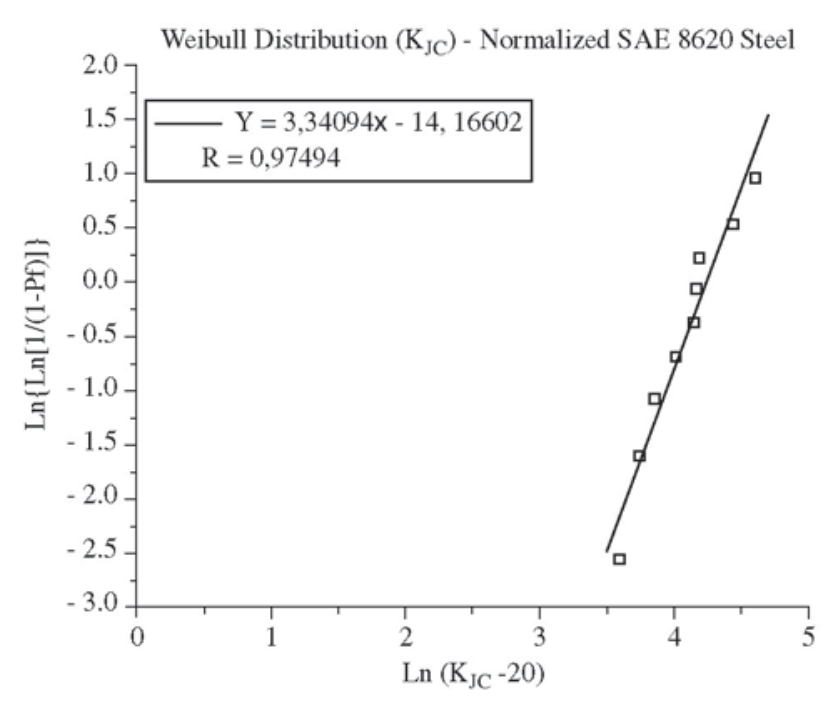

(b)

Figure 7. Master Curve and its tolerance limits: a) and Weibull distribution for crack initiation; b) SAE 8620 steel CR specimens, normalized condition, at $-88^{\circ} \mathrm{C}$.

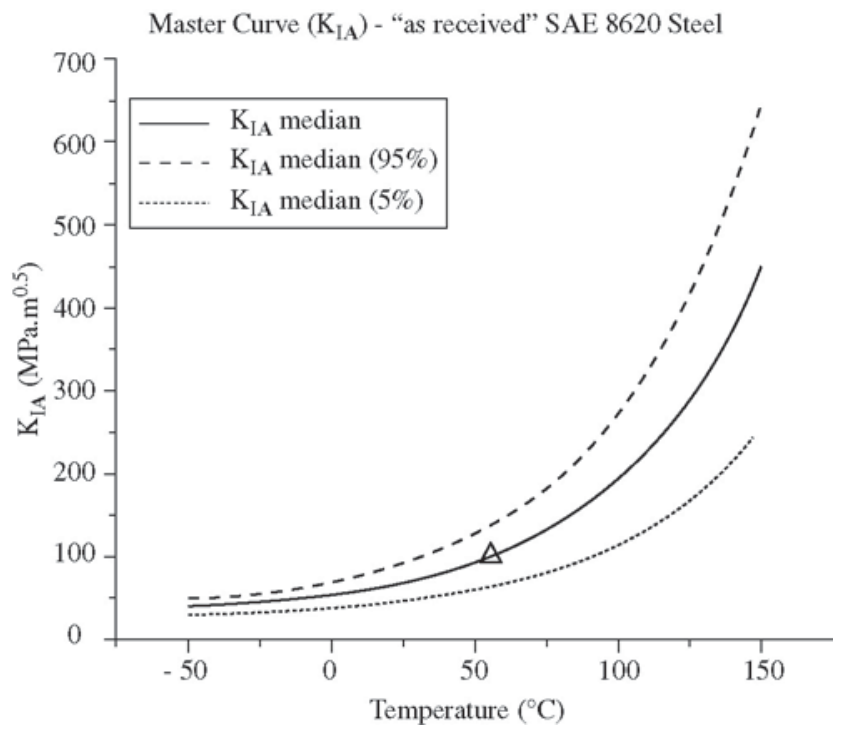

(a)

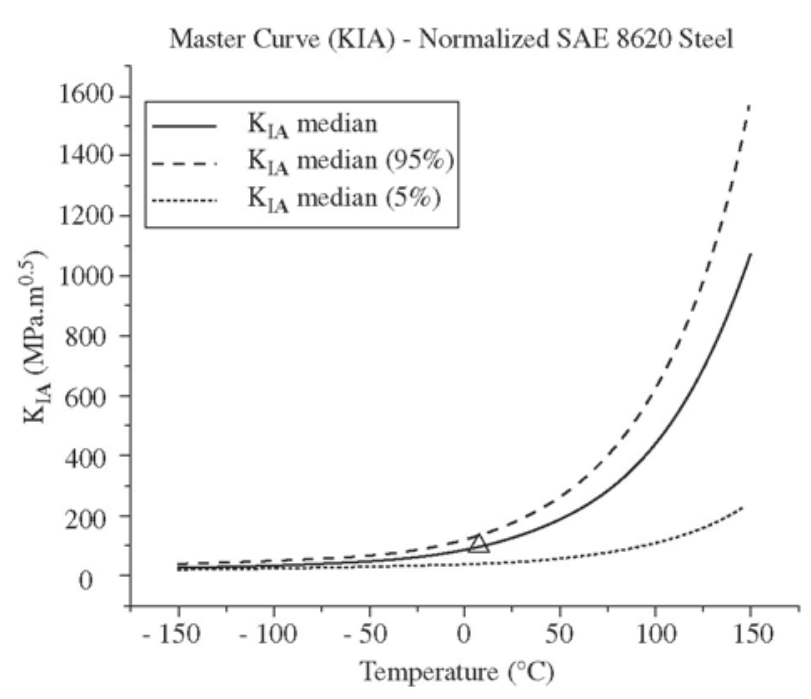

(b)

Figure 8. Master Curve and its tolerance limits for crack arrest, SAE 8620 steel CR specimens: a) "as received"; b) normalized conditions. 
Table 4. Experimental values of $\mathrm{J}_{\mathrm{C}}$, and calculated $\mathrm{K}_{\mathrm{JC}}$ and $\mathrm{T}_{0}$ at $-88^{\circ} \mathrm{C}$.

\begin{tabular}{|c|c|c|c|c|c|}
\hline $\begin{array}{c}\mathrm{J}_{\mathrm{C}} \\
\left(\mathrm{kJ} . \mathrm{m}^{2}\right)\end{array}$ & $\begin{array}{l}\mathrm{K}_{\mathrm{JC}}(0,39 \mathrm{~T}) \\
\left(\mathrm{MPa} \mathrm{m}^{1 / 2}\right)\end{array}$ & $\begin{array}{c}\mathrm{K}_{\mathrm{JC}}(1 \mathrm{~T}) \\
\left(\mathrm{MPa} \mathrm{m}^{1 / 2}\right)\end{array}$ & $\begin{array}{c}\mathrm{K}_{\mathrm{JC}}(\mathrm{med}) \\
\left(\mathrm{MPa} \cdot \mathrm{m}^{1 / 2}\right)\end{array}$ & $\begin{array}{l}\text { Test Temperature } \\
\left({ }^{\circ} \mathrm{C}\right)\end{array}$ & $\begin{array}{c}\mathrm{T}_{0} \\
\left({ }^{\circ} \mathrm{C}\right)\end{array}$ \\
\hline 20.74 & 66.0 & 56.4 & & & \\
\hline 101.38 & 145.9 & 119.7 & & & \\
\hline 38.52 & 89.9 & 75.4 & & & \\
\hline 49.09 & 101.5 & 84.6 & & & \\
\hline 25.72 & 73.5 & 62.4 & 84.96 & -88 & -75.3 \\
\hline 50.83 & 103.3 & 86.0 & & & \\
\hline 77.49 & 127.6 & 105.2 & & & \\
\hline 30.17 & 79.6 & 67.2 & & & \\
\hline 47.45 & 99.8 & 83.2 & & & \\
\hline
\end{tabular}

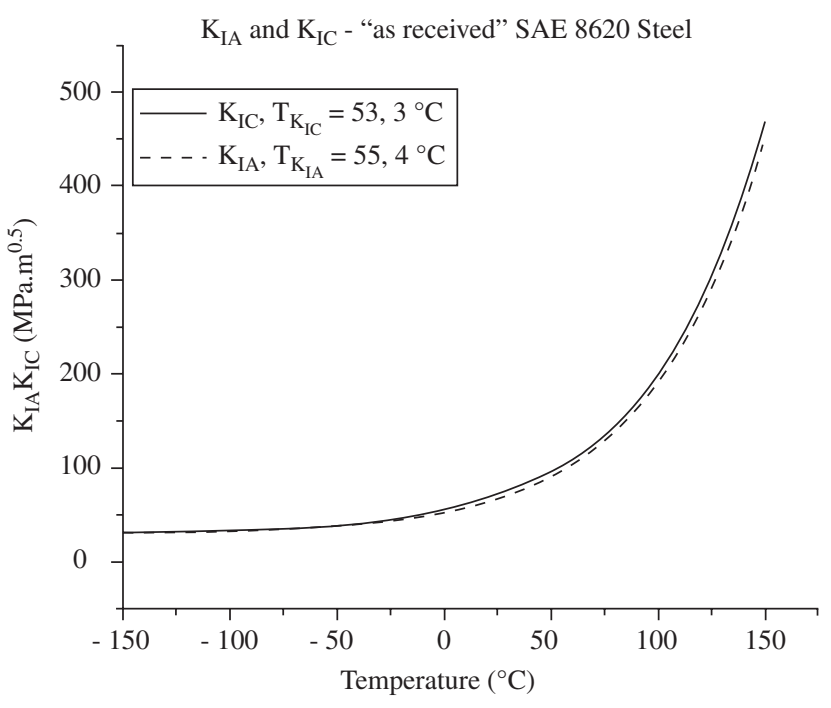

(a)

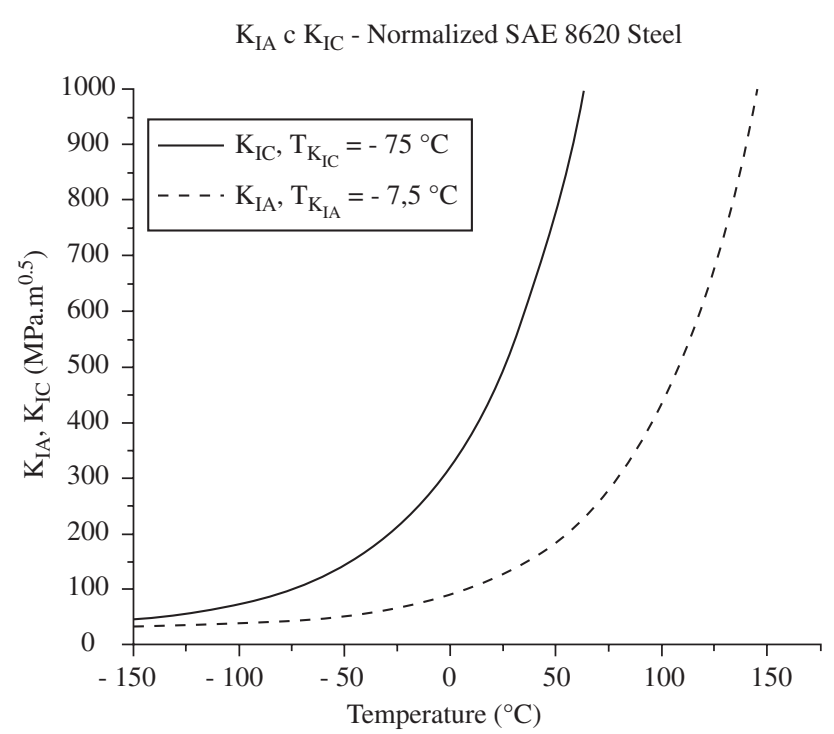

(b)

Figure 9. Master curves comparison for crack arrest and crack initiation in SAE 8629 steel in: a)“as received”; b)normalized conditions.

\section{References}

1. U.S. Nuclear Regulatory Commission. International Comparative Assessment Study of Pressurized Thermal Shock in Reactor Pressure Vessels. Nureg/Cr-6651, Ornl/Tm-1999/231, Washington: Oak Ridge Natio0nal Laboratory; 1999.

2. Mishima, Y, Ishino S, Ishikawa M, Okamura H, Yagawa G, Hidaka T et al. PTS Integrity Study in Japan. International Journal of Pressure Vessels and Piping. 1994; 58(1):91-101.

3. Stalkopf K E. Pressure vessel integrity under pressurized thermal shock conditions. Nuclear Engineering and Design. 1994. 80(2):80-171.

4. Jeong S, Jang C, Park J, Hong S, Jin T, Yuem H et al. Lessons learned from plant-specific PTS integrity analysis on a embrittled reactor pressure vessel. International Journal of Pressure Vessels and Piping. 2001; 78(2):99-109
5. Barroso, S P. Análise de tensão no Circuito primário do Reator. [Unpublished Master Thesis]. Belo Horizonte: Universidade Federal de Minas gerais; 1995.

6. Planman T, Wallin K, Rintamaa R. Evaluating crack arrest fracture toughness from Charpy impact testing. In: Transactions of the 14th International Conference on Structural Mechanics in Reactor Technology(SMIRT 14);1997 Aug 17-22; Lyon, France.

7. American Society of Testing Materials. Test Method for Notched Bar Testing of Metallic Materials. Annual Book of ASTM. 2001; vol. 03.01. (ASTM E-23/00)

8. American Society of Testing Materials. Standard Test Methods for Tension Testing of Metallic Materials. 2001 (ASTM E 8-00b).

9. American Society of Testing Materials. Test Method for determination of reference temperature, T0, for ferritic steels in the transition range. Annual Book of ASTM. 2001; vol. 03.01. (ASTM E1921-00). 